\title{
Therapeutic Effects of Zinc on Patients Who Have Sudden Sensorineural Hearing Loss with Normal Serum Zinc Level
}

\author{
Yu Ri Kim and Yee Hyuk Kim \\ Department of Otorhinolaryngology-Head \& Neck Surgery, School of Medicine, Catholic University of Daegu, Daegu, Korea
}

\section{혈청 아연 농도가 정상인 돌발성 난청 환자에서 아연의 치료 효과}

김 유 리·김 이 혁

대구가톨릭대학교 의과대학 이비인후과학교실

Received April 7,2015

Revised August 26, 2015

Accepted August 26, 2015

Address for correspondence

Yee Hyuk Kim, MD

Department of Otorhinolaryngology-

Head \& Neck Surgery,

School of Medicine,

Catholic University of Daegu,

33 Duryugongwon-ro 17-gil,

Nam-gu, Daegu 42472, Korea

Tel $+82-53-650-3489$

Fax +82-53-650-4533

E-mail yhukim@cu.ac.kr
Background and Objectives Zinc has antioxidant effect, anti-inflammatory effect and neuromodulative function. The purpose of this study was to investigate whether treatment with zinc can improve the outcome of sudden sensorineural hearing loss (SSNHL).

Subjects and Method The study group consisted of 143 patients diagnosed as SSNHL. Of the patients, 82 were given corticosteroid treatment (group $\mathrm{Ct}$ ) and 61 were given oral zinc plus corticosteroid treatment (group Zn). In group Zn, serum zinc level was checked before treatment and the patients with normal serum zinc level were included. Hearing was assessed before therapy and at 2 weeks, 1 month and 2 months after the initiation of therapy.

Results A significantly larger hearing gain in pure tone average (group Ct vs. group $\mathrm{Zn}=26.40 \mathrm{~dB}$ HL vs. $34.28 \mathrm{~dB} \mathrm{HL}$ ) and at $2000 \mathrm{~Hz}$ (group Ct vs. group $\mathrm{Zn}=24.93 \mathrm{~dB} \mathrm{HL}$ vs. $33.60 \mathrm{~dB} H L$ ) and $8000 \mathrm{~Hz}$ (group Ct vs. group $\mathrm{Zn}=11.64 \mathrm{~dB}$ HL vs. $20.66 \mathrm{~dB} \mathrm{HL}$ ) were seen in group $\mathrm{Zn}$ compared with the group $\mathrm{Ct}$.

Conclusion Oral zinc supplementation may have beneficial effects in the treatment of SSNHL, especially at 2000 and $8000 \mathrm{~Hz}$.

Korean J Otorhinolaryngol-Head Neck Surg 2015;58(12):831-5

Key Words Sudden hearing loss $\cdot$ Zinc.

\section{서 론}

바이러스 감염과 내이의 순환 장애 등이 돌발성 난청의 주 된 발병 기전으로 생각되고 있으나, 실제 진료 현장에서 돌발 성 난청 환자의 발생 원인을 명확하게 찾지 못하는 경우가 많 다. ${ }^{1-3)}$ 그래서 치료는 바이러스 감염과 내이의 순환 장애 등 가 능성이 있는 발병 원인의 개선을 위해서 여러 가지 약물을 동 시에 사용하고 있다. ${ }^{2)}$ 그중에 가장 대표적인 것이 스테로이드 이며, 이 약제의 항염증 효과가 청력 회복에 큰 역할을 하는 것으로 추정하고 있다.") 그리고 마그세슘(magnesium), 비타 민 $\mathrm{E}$ 와 같은 항산화제가 돌발성 난청 치료에 효과가 있다는
보고도 있다.,6) 아연(zinc)은 위에 언급된 항염증 및 항산화 작용을 가지고 있는 것으로 알려져 있다. ${ }^{2,7)}$ 스트레스로 인한 코티졸(cortisol) 등의 스트레스 호르몬 증가가 돌발성 난청의 원인 중 하나로 제시되고 있으므로, ${ }^{8-10)}$ 돌발성 난청에서 스테 로이드를 사용하는 것은 부족한 호르몬의 보충이라기보다는 항염증 작용을 통한 청력 향상이 목적이라고 볼 수 있겠다. 그 러므로 항염증 및 항산화 작용 등이 있다고 알려져 있는 아연 의 경우, 혈청 아연 농도가 정상인 돌발성 난청 환자에서 치료 효과가 있는지 알아보고자 하였다. 


\section{대상 및 방법}

\section{대 상}

돌발성 난청은 연속하는 세 주파수 이상에서 $30 \mathrm{~dB}$ 이상의 난청이 3일 이내에 갑자기 진행한 경우로 정의하였다. 이 기준 을 만족하지만 양측성인 경우, 임신을 한 경우, 증상 발생 직전 에 두부 외상이 있었던 경우, 중추신경계 질환(두개내 종양, 뇌출혈 등)이 있는 경우, 그리고 재발성인 경우는 제외하였다. 입원은 증상 발생 7 일 이내에 하고 입원일 기준으로 2 개월 이 상 경과 관찰이 가능했던 환자를 대상으로 하였다. 2008년 1 월부터 2013년 5월까지 단일 의료기관에서 입원 치료를 받은 돌발성 난청 환자 중 위의 기준을 만족하는 143 명을 대상으 로 후향적으로 의무기록을 분석하였다. 이 중 2008년 1월부터 2011년 4월까지 경구 아연을 복용하지 않은 그룹(대조군, group Ct) 82명과 2011년 5월부터 2013년 5월까지 이전의 치료에 추 가로 아연을 경구로 복용한 그룹(실험군, group $\mathrm{Zn)} \mathrm{61명을} \mathrm{분}$ 석 대상으로 하였다. 두 그룹 모두 6일 동안 입원하였으며 입 원 기간 동안 덱사메타손 $10 \mathrm{mg}$ (dexamethasone ${ }^{\circledR}$, Jeil Pharm, Seoul, Korea)을 정맥 투여하였으며 퇴원 후에는 경 구 메칠프레드니소론(Methylon ${ }^{\circledR}, 4 \mathrm{mg} / \mathrm{lT}$, KunWha Pharm, Seoul, Korea)으로 8일 동안 감량하였다. 그 외에 carbogen 흡인 치료, 저분자량 혈량증량제(Dextran ${ }^{\circledR}$, DaiHan Pharm, Seoul, Korea), 펜톡시피린 $400 \mathrm{mg}$ (Trental ${ }^{\circledR}$, HanDok Pharm, Seoul, Korea), 플루나리진 5 mg(Sibelium ${ }^{\circledR}$, Janssen Korea, Seoul, Korea) 복용과 별신경절차단술을 시행하였다. Group Zn에서만 경구 아연을 추가로 복용하였다.

\section{아연의 측정과 복용}

혈청 아연 농도는 입원하여 아연제제를 복용하기 전에 group $\mathrm{Zn}$ 에서만 측정하였으며, 그 결과가 정상 범위(66 120 $\mu \mathrm{g} / \mathrm{dL})$ 에 해당되는 환자만을 분석 대상으로 하였다. Group $\mathrm{Zn}$ 에서만 아 연을 복용하였는데 아연[Zinkistin ${ }^{\circledR}$, Zinc histidine dehydrate 94 mg(15 mg as Zinc), Pharmbio Korea, Seoul, Koreal은 입 원하였을 때 투여하기 시작하였으며, 환자는 하루에 두 캡슐
을 2 개월 동안 복용하였다. 아연 복용에 대한 동의서는 환자 들에게 모두 받았다.

\section{청력검사 및 평가방법}

돌발성 난청으로 진단된 후 순음청력검사는 입원 중에는 매일하였으며 그 이후에는 입원일을 기준으로 2주, 1 개월, 2개 월째 시행하였다. 청력은 $250,500,1000,2000,4000$, 그리고 $8000 \mathrm{~Hz}$ 에서 역치를 측정하였으며, 평균 청력 역치는 500 , 1000,2000 , 그리고 $4000 \mathrm{~Hz}$ 의 기도 청력 역치의 평균값으로 정하였다. 평균 청력 역치와 $250 \mathrm{~Hz}$ 에서 $8000 \mathrm{~Hz}$ 까지 측정한 6 개의 주파수별 청력 개선 정도, 그리고 Siegel's criteria를 이 용하여 치료 효과를 판정하였다. 통계적 분석은 SPSS version 19(SPSS Inc., Chicago, IL, USA)를 이용하여 chi-square test, t-test의 방법으로 분석하였으며, $p$ 값이 0.05 이하인 경우 에 통계학적 의의가 있는 것으로 판정하였다.

\section{결 과}

Group $\mathrm{Ct}$ 의 치료에 아연의 경구 복용을 추가하여 치료한 환자 중 혈청 아연 수치가 정상인 환자군을 group $\mathrm{Zn}$ 으로 하 였으며 group $\mathrm{Ct}$ 는 82명, group $\mathrm{Zn}$ 은 61명이었다. group $\mathrm{Zn}$ 의 평균 아연 수치는 96.92 $\pm 19.73 \mu \mathrm{g} / \mathrm{dL}$ (정상 범위: 66 120 $\mu \mathrm{g}$ / $\mathrm{dL}$ )였다. 두 군의 나이, 남녀 비율, 이환된 귀의 위치, 증상 발 생부터 치료 시작까지 소요된 시간, 이명, 어지럼증, 고혈압, 당뇨 병의 비율은 유의한 차이가 없었다(Table 1).

증상 발생 후, 치료 시행 전 최초로 측정된 순음청력검사에 서 평균 청력 역치와 주파수별 역치는 두 군에서 유의한 차이 가 없었다(Table 2). 치료 후 두 군의 청력을 비교하였을 때 최 종 평균 청력 역치(final pure tone average)는 두 군 사이에 유 의한 차이가 없었지만, 청력 향상 정도(hearing gain)는 group $\mathrm{Zn}$ 이 더 높았으며 유의한 차이(group Ct vs. group $\mathrm{Zn}=26.40$ $\mathrm{dB} \mathrm{HL}$ vs. $34.28 \mathrm{~dB} \mathrm{HL}, p=0.043)$ 를 보였다. 청력 향상 정도 를 주파수별로 비교하였을 때, 비교 대상이 된 6개 주파수(250, $500,1 \mathrm{k}, 2 \mathrm{k}, 4 \mathrm{k}, 8 \mathrm{kHz}$ ) 모두 group $\mathrm{Zn}$ 에서 더 많이 호전되었

Table 1. Demographic and clinical characteristics of patients

\begin{tabular}{|c|c|c|c|}
\hline & Group Ct $(n=82)$ & Group Zn $(n=61)$ & $p$ \\
\hline Age & $46.64 \pm 15.46$ & $50.00 \pm 13.51$ & 0.181 \\
\hline Sex (male:female) & $38: 44$ & $24: 37$ & 0.404 \\
\hline Site (right:left) & $36: 46$ & $30: 31$ & 0.531 \\
\hline Period from onset to visit (days) & $3.90 \pm 2.17$ & $3.37 \pm 2.59$ & 0.202 \\
\hline Tinnitus & $57(69.5 \%)$ & $48(78.7 \%)$ & 0.219 \\
\hline Dizziness & $15(18.3 \%)$ & $13(21.3 \%)$ & 0.653 \\
\hline Hypertension & $20(24.4 \%)$ & $14(23.0 \%)$ & 0.842 \\
\hline Diabetes mellitus & $11(13.4 \%)$ & $10(16.4 \%)$ & 0.619 \\
\hline
\end{tabular}


지만 $2000 \mathrm{~Hz}$ (group Ct vs. group $\mathrm{Zn}=24.93 \mathrm{~dB} \mathrm{HL}$ vs. 33.60 $\mathrm{dB} \mathrm{HL}, p=0.043$ )와 $8000 \mathrm{~Hz}$ (group Ct vs. group $\mathrm{Zn}=11.64$ $\mathrm{dB}$ HL vs. $20.66 \mathrm{~dB}$ HL, $p=0.015)$ 에서만 통계적으로 유의한 차이를 보였다(Table 3). Siegel's criteria를 기준으로 최종 청력 이 사회적응청력(serviceable hearing)에 해당하는 complete recovery군과 partial recovery군을 청력 호전군으로 보았을 때 청력 호전율은 group $\mathrm{Zn}$ 에서 더 높게 나타났으나, 두 군 사 이에 통계적으로 유의한 차이는 없었다(Table 4).

아연을 복용한 group $\mathrm{Zn}$ 에서 구역 및 구토, 위장관 장애, 미 각변화, 그리고 구강 건조 등의 부작용이 나타난 환자는 없었다.

\section{고 찰}

외인성 아연의 흡수와 내인성 아연의 분비/배설이 아연의 항상성 유지의 핵심인데, 외인성 아연의 주된 흡수 위치는 소
장 근위부(십이지장, 공장)로 알려져 있으며, 소장 근위부 융모 에 있는 아연 운반체가 아연의 세포 내 섭취와 세포 외 유출 에 관여하고, 아연이 소장세포로 유입된 후 문맥순환(portal circulation)으로 운반되어, 아연의 약 $60 \%$ 는 골격근, $30 \%$ 는 뼈, $5 \%$ 는 간과 피부에 저장되고 나머지는 뇌, 신장, 췌장과 같 은 조직에 분배된다. ${ }^{11,12)}$ 혈청 아연은 체내 총 아연의 $0.1 \%$ 정 도이며 $80 \%$ 는 알부민과 느슨하게 결합되어 있으며, $20 \%$ 는 알 파2-마크로글로불린과 단단하게 결합되어 있다. ${ }^{12}$ 체내 아연 의 $0.1 \%$ 정도가 매일 음식을 통해 보충되는데, 장내(intestinal lumen)에 존재하는 아연의 양, 흡수를 촉진하는 음식 (예: 모유, 동물성 단백질), 또는 흡수를 억제하는 음식(예: 콩, 칼슘제)이 아연 흡수에 영향을 준다. ${ }^{11,12)}$ 췌장과 담도의 분비 물, 위십이지장의 분비물, 탈피된 점막세포가 내인성 아연의 원천이며 재흡수는 소장에서 이루어지지만 외인성 아연의 흡 수보다는 원위부라고 여겨지고 있다. ${ }^{11}$

Table 2. Audiologic features of patients before starting treatment

\begin{tabular}{lccc}
\hline \multicolumn{1}{c}{ Pure tone audiometry } & Group $\mathrm{Ct}(\mathrm{n}=82)(\mathrm{dB} \mathrm{HL})$ & Group $\mathrm{Zn}(\mathrm{n}=61)(\mathrm{dB} \mathrm{HL})$ & $\mathrm{p}$ \\
\hline Average $[(0.5 \mathrm{k}+1 \mathrm{k}+2 \mathrm{k}+4 \mathrm{kHz}) / 4]$ & $66.17 \pm 19.39$ & $69.40 \pm 18.87$ & 0.320 \\
$250 \mathrm{~Hz}$ & $68.05 \pm 20.93$ & $67.37 \pm 24.28$ & 0.860 \\
$500 \mathrm{~Hz}$ & $68.17 \pm 22.30$ & $69.93 \pm 22.74$ & 0.643 \\
$1000 \mathrm{~Hz}$ & $68.11 \pm 20.57$ & $70.90 \pm 20.93$ & 0.427 \\
$2000 \mathrm{~Hz}$ & $64.51 \pm 22.34$ & $68.69 \pm 21.31$ & 0.261 \\
$4000 \mathrm{~Hz}$ & $63.90 \pm 24.82$ & $68.11 \pm 24.77$ & 6.317 \\
$8000 \mathrm{~Hz}$ & $62.50 \pm 19.88$ & $67.38 \pm 17.64$ & 0.130 \\
\hline
\end{tabular}

Table 3. Comparison of hearing gain in PTA and improvement of hearing threshold according to frequency between group Ct and group Zn

\begin{tabular}{lccc}
\hline & Group Ct $(\mathrm{n}=82)$ & Group Zn $(\mathrm{n}=61)$ & $\mathrm{p}$ \\
\hline Initial PTA $(\mathrm{dB} \mathrm{HL})$ & $66.17 \pm 19.39$ & $69.40 \pm 18.87$ & 0.320 \\
Final PTA $(\mathrm{dB} \mathrm{HL})$ & $39.77 \pm 22.72$ & $35.12 \pm 25.43$ & 0.252 \\
Hearing gain $(\mathrm{dB} \mathrm{HL})$ & & & \\
$\quad$ Average $(0.5 \mathrm{k}, 1 \mathrm{k}, 2 \mathrm{k}, 4 \mathrm{kHz})$ & $26.40 \pm 21.78$ & $34.28 \pm 24.21$ & $0.043^{*}$ \\
$250 \mathrm{~Hz}$ & $30.85 \pm 26.92$ & $35.40 \pm 28.94$ & 0.334 \\
$500 \mathrm{~Hz}$ & $33.10 \pm 28.94$ & $40.09 \pm 29.23$ & 0.157 \\
$1000 \mathrm{~Hz}$ & $29.26 \pm 28.30$ & $37.62 \pm 27.44$ & 0.079 \\
$2000 \mathrm{~Hz}$ & $24.93 \pm 24.96$ & $33.60 \pm 25.39$ & $0.043^{*}$ \\
$4000 \mathrm{~Hz}$ & $18.59 \pm 19.69$ & $25.81 \pm 23.98$ & 0.057 \\
$8000 \mathrm{~Hz}$ & $11.64 \pm 18.66$ & $20.66 \pm 23.58$ & $0.015^{*}$ \\
\hline
\end{tabular}

$* p<0.05$. PTA: pure tone average

Table 4. Type of Siegel's criteria and hearing improvements based on Siegel's criteria

\begin{tabular}{|c|c|c|c|c|}
\hline Type & Hearing recovery & Group Ct $(n=82)$ & Group Zn $(n=61)$ & $p$ \\
\hline Complete recovery $(\mathrm{A})$ & Final hearing better than $25 \mathrm{~dB}$ & 26 & 28 & - \\
\hline Partial recovery (B) & $\begin{array}{l}\text { More than } 15 \mathrm{~dB} \text { gain and } \\
\text { final hearing } 25-45 \mathrm{~dB}\end{array}$ & 15 & 10 & - \\
\hline Slight improvement (C) & $\begin{array}{l}\text { More than } 15 \mathrm{~dB} \text { gain and } \\
\text { final hearing poorer than } 45 \mathrm{~dB}\end{array}$ & 10 & 8 & - \\
\hline No improvement (D) & $\begin{array}{l}\text { Less than } 15 \mathrm{~dB} \text { gain, } \\
\text { final hearing poorer than } 75 \mathrm{~dB}\end{array}$ & 31 & 15 & - \\
\hline$A+B / C+D$ & - & $41 / 41(50.0 \%)$ & $38 / 23(62.3 \%)$ & 0.144 \\
\hline
\end{tabular}


아연은 항산화 작용, 항염증 작용, 그리고 신경조정기능 (neuromodulation)을 가지고 있고, 와우 조직에 많이 분포하 고 있는 것으로 알려져 있어 청력 유지에 중요한 역할을 하는 것으로 여겨지고 있다.,7,13-18) 아연은 항산화 작용을 한다. 아연 은 superoxide dismutase(SOD) 구성에 중요한 역할을 하고, 자유 라디칼의 생성에 관여하는 nicotinamide adenine dinucleotide phosphate oxidase를 억제하며, 메탈로티오네인 (metallothionein) 생성에 관여함으로써 항산화 작용을 하게 되는데, 특히 와우 조직에서는 $\mathrm{Cu} / \mathrm{Zn} \mathrm{SOD}$ 의 형태로 존재하 면서 혈관조의 기능 유지에 중요한 역할을 한다. ${ }^{15,16,18)}$ 그러므 로 아연이 부족한 경우 $\mathrm{SOD}$ 의 활성도가 감소하여 산화 스트 레스에 취약하게 된다. ${ }^{15)}$ 그리고 허혈 후 발생하는 $\cdot \mathrm{OH}$ 의 형 성을 감소시켜 허혈성 손상을 줄임으로써 해당 장기의 기능 회복에 도움이 된다는 보고도 있다. ${ }^{15,16)}$ 내이의 혈액 순환 장 애가 돌발성 난청의 가능성 있는 주요한 원인으로 여겨지고 있으므로 아연의 이런 역할로 인해 돌발성 난청의 치료에 도 움이 될 수 있을 것으로 생각된다. 아연은 항염증 작용을 한 다. 아연은 단핵구와 대식세포의 아연 의존성 전사인자인 $\mathrm{A} 20$ 을 유도하여 $\mathrm{NF}-\kappa \mathrm{B}$ 의 활성을 억제함으로써 인터루킨-1 과 종양괴사인사-알파 등의 시토카인과 세포 간 부착 분 자-1(intercellular adhesion molecule-1)과 혈관 내피세포 부 착 분자-1(vascular cell adhesion molecule-1) 등의 부착 분자 (adhesion molecule)의 생성을 감소시킴으로써 항염증 작용 을 한다. ${ }^{16,19,20)}$ 바이러스 감염이 돌발성 난청의 주요한 원인 중 하나로 생각되고 있고, 그래서 스테로이드를 고용량으로 사용 하고 있으므로 여기에 아연을 함께 사용하면 항염증 작용을 증대시킬 수 있을 것으로 예상할 수 있다. 아연은 신경조정기 능이 있다. 청신경의 시냅스에 존재하면서 시냅스 활성이 있는 동안 아연이 분비되어 칼슘의 항상성을 조정함으로써 신경 전 달을 조정한다. ${ }^{17)} \mathrm{CBA}$ mice를 대상으로 한 연구에서, 아연이 부족한 경우 청성 뇌간 유발 반응 검사에서 청력 역치 상승이 고주파에서 뚜렷하였고, 아연을 정상적으로 복용한 후에는 상승했던 고주파의 역치가 정상으로 회복되었다.) 하지만 변 조 이음향 방사 검사에서는 역치 변화가 없어 내유모세포와 청신경의 신경조정기능의 이상을 고주파 역치 상승의 원인으 로 추정하였다.) 이러한 사실로 아연이 고주파의 청력과 연관 이 있다고 유추할 수 있는데, 본 연구에서도 아연을 복용한 경 우 $2 \mathrm{kHz}(p=0.043)$ 와 $8 \mathrm{kHz}$ ( $p=0.015)$ 에서 뚜렷한 청력 향상 이 있었으며, $4 \mathrm{kHz}$ 에서는 $p$ 값이 통계적 유의 수준에 매우 가 까운 수치 $(p=0.057)$ 를 보여, 돌발성 난청에서 저주파보다는 고 주파의 청력 향상에 아연이 도움이 되는 것으로 생각된다.

돌발성 난청의 가능성 있는 원인은 바이러스 감염, 내이의 혈액 순환 장애 등이 있으며 환자 개별적으로 각각의 원인을
명확하게 찾지 못하는 경우가 많아 가능성 있는 원인들에 대 해 여러 가지 약제를 동시에 사용하고 있다. 이 약제 중 대표 적인 것이 스테로이드로서, 돌발성 난청 환자에서 코티졸 수치 가 낮아서 스테로이드를 투여하는 것이 아니라 항염증 작용 을 기대하고 사용하고 있다. 마찬가지로 돌발성 난청 환자에 서 혈청 아연 농도가 낮은 경우가 아니라 정상인 경우에서 아 연의 항산화, 항염증 작용, 그리고 신경조정기능이 돌발성 난 청 치료에 도움이 되는지 알아보고자 하였다. Siegel's criteria를 기준으로 한 청력 호전군(complete recovery와 partial recovery)의 비율과 저주파의 청력 향상 정도는 group $\mathrm{Zn}$ 에서 더 높 게 나타났으나 통계적으로 두 군 간에 유의한 차이는 없었다. 하지만 group $\mathrm{Zn}$ 에서 순음청력검사의 평균 청력 역치를 기준 으로 한 청력 향상 정도와 2000과 $8000 \mathrm{~Hz}$ 에서의 청력 향상 정도가 통계적으로 의미 있게 높은 것으로 나타났고, 4000 $\mathrm{Hz}$ 에서는 통계적 유의 수준에 매우 가까웠다. 그러므로 혈청 아연 농도가 정상이라고 하더라도 기존의 돌발성 난청 치료와 병행하여 추가로 아연을 경구 복용하는 것이 고주파의 청력 향상에 도움이 될 것으로 추정해 볼 수 있겠다.

Group $\mathrm{Ct}$ 의 혈청 아연 수치와 group $\mathrm{Zn}$ 에서 아연을 복용 한 후의 혈청 아연 수치를 측정하지 않았고, 위약군이 없으며, 스테로이드와 아연 이외에 다른 치료도 병행되었다는 점, 그 리고 후향적 연구로 두 군 간의 동질성이 완벽하게 확보되지 못한 점이 본 연구의 한계점이 되겠지만, 혈청 아연 수치가 정 상인 환자를 대상으로 한 것과 돌발성 난청에서 아연을 복용 하였을 때 청력 향상 여부와 정도를 주파수별로 비교한 점은 이전 연구와의 차별점이라고 할 수 있다. 그래서 혈청 아연 수 치만 봤을 때는 아연 복용이 필요하지 않지만 돌발성 난청인 경우에는 정상 혈청 아연 수치라도 아연을 복용하는 것이 치 료에 도움이 될 가능성은 있어 보인다. 고실 내 스테로이드 주 사법이 저주파에 효과가 있다는 보고가 있는 것처럼, 아연을 복용하였을 때는 고주파에 효과가 있을 것으로 추정해 볼 수 있을 것이고 이것은 동물 실험에서도 상응하는 결과가 보고된 바 있다. ${ }^{711}$ 하지만 보다 직접적인 근거를 만들기 위해서는 전향 적인 이중맹검 무작위 대조군 연구가 필요할 것으로 생각된다. 결론적으로, 혈청 아연 농도가 정상인 돌발성 난청 환자에서 기존의 치료에 추가로 아연을 경구 복용하는 것이 청력 향상에 도움이 되고, 다른 주파수에 비해 $2000 \mathrm{~Hz}$ 와 $8000 \mathrm{~Hz}$ 에서 청 력이 더 향상될 가능성이 있음을 추정해 볼 수 있었다.

\section{REFERENCES}

1) Kang WS, Kim YH, Park KH, Seo MW, Son EJ, Yoo SY, et al. Treatment strategy for sudden sensorineural hearing loss. Korean J Otorhinolaryngol-Head Neck Surg 2011;54(10):675-82.

2) Yang CH, Ko MT, Peng JP, Hwang CF. Zinc in the treatment of 
idiopathic sudden sensorineural hearing loss. Laryngoscope 2011;121(3):617-21.

3) Park MK, Lee JD, Lee BD, Lim HW, Hwang SJ, Chae SW. Clinical usefulness of viral IgM antibody test in sudden sensorineural hearing loss patient. Korean J Otorhinolaryngol-Head Neck Surg 2011;54 (1):37-42.

4) Park HH, Choi JH, Huh EJ, Lee TH, Nam JK, Kwon JK. Comparison of the effect of high-dose steroid with that of super-high-dose steroid therapy in sudden sensorineural hearing loss. Korean J OtorhinolaryngolHead Neck Surg 2009;52(7):566-71.

5) Gordin A, Goldenberg D, Golz A, Netzer A, Joachims HZ. Magnesium: a new therapy for idiopathic sudden sensorineural hearing loss. Otol Neurotol 2002;23(4):447-51.

6) Joachims HZ, Segal J, Golz A, Netzer A, Goldenberg D. Antioxidants in treatment of idiopathic sudden hearing loss. Otol Neurotol 2003; 24(4):572-5.

7) Kang WS, Lim HW, Suh JK, Chung JW. Effects of a zinc-deficient diet on hearing in CBA mice. Neuroreport 2012;23(4):201-5.

8) Schmitt C, Patak M, Kröner-Herwig B. Stress and the onset of sudden hearing loss and tinnitus. Int Tinnitus J 2000;6(1):41-9.

9) van Cruijsen N, Dullaart RP, Wit HP, Albers FW. Analysis of cortisol and other stress-related hormones in patients with Ménière's disease. Otol Neurotol 2005;26(6):1214-9.

10) ten Cate WJ, Curtis LM, Small GM, Rarey KE. Localization of glucocorticoid receptors and glucocorticoid receptor mRNAs in the rat cochlea. Laryngoscope 1993;103(8):865-71.

11) Krebs NF. Overview of zinc absorption and excretion in the human gastrointestinal tract. J Nutr 2000;130(5S Suppl):1374S-7S.
12) Kambe T, Tsuji T, Hashimoto A, Itsumura N. The physiological, biochemical, and molecular roles of zinc transporters in zinc homeostasis and metabolism. Physiol Rev 2015;95(3):749-84.

13) Fraker PJ. Roles for cell death in zinc deficiency. J Nutr 2005;135(3): 359-62.

14) Tapiero H, Tew KD. Trace elements in human physiology and pathology: zinc and metallothioneins. Biomed Pharmacother 2003;57 (9):399-411.

15) Powell SR. The antioxidant properties of zinc. J Nutr 2000;130(5S Suppl):1447S-54S.

16) Prasad AS, Beck FW, Bao B, Snell D, Fitzgerald JT. Duration and severity of symptoms and levels of plasma interleukin-1 receptor antagonist, soluble tumor necrosis factor receptor, and adhesion molecules in patients with common cold treated with zinc acetate. J Infect Dis 2008;197(6):795-802.

17) Zirpel L, Parks TN. Zinc inhibition of group I mGluR-mediated calcium homeostasis in auditory neurons. J Assoc Res Otolaryngol 2001;2(2):180-7.

18) Rarey KE, Yao X. Localization of $\mathrm{Cu} / \mathrm{Zn}-\mathrm{SOD}$ and $\mathrm{Mn}-\mathrm{SOD}$ in the rat cochlea. Acta Otolaryngol 1996;116(6):833-5.

19) Merchant SN, Adams JC, Nadol JB Jr. Pathology and pathophysiology of idiopathic sudden sensorineural hearing loss. Otol Neurotol 2005;26 (2):151-60.

20) Merchant SN, Durand ML, Adams JC. Sudden deafness: is it viral? ORL J Otorhinolaryngol Relat Spec 2008;70(1):52-60; discussion 60-2.

21) Ahn JH, Yoo MH, Yoon TH, Chung JW. Can intratympanic dexamethasone added to systemic steroids improve hearing outcome in patients with sudden deafness? Laryngoscope 2008;118(2):279-82. 